\title{
Child Protection and Corporate Zakat
}

\author{
Mohammad Mahbubi Ali*
}

Issues of child abuse, neglect, malnutrition and exploitation are the focus of renewed attention amongst governments, policymakers and multilateral institutions. For instance, the United Nations Millennium Declaration 2005 and the Sustainable Development Goals (SDG) 2017 have listed children's rights to survival, health, and education as their main agendas.

Research has shown that children are the most vulnerable segments of society, being exposed to abuse and violence. Each year, an estimated 0.5 to 1.5 billion children are involved in physical violence, 150 million girls and 73 million boys are raped or subjected to sexual abuse, 115 million children are engaged in dangerous work, and 264 million children have no access to school.

In Malaysia, 17.7 per cent of children below the age of 5 are stunted (Health Ministry 2017 records), 22 per cent are underweight, and 23 per cent are either overweight or obese (United Nations Children's Fund [UNICEF] 2018). The Malaysian government and policymakers, therefore, have shifted their attention towards strengthening the social protection system. For example, the Bantuan Sara Hidup (BSH) programme launched in 2018 offers unconditional cash transfers to B40 households to assist with rising costs of living. However, the existing protection schemes are not specifically designed to address the welfare of children during their first 1,000 days - the most vulnerable phase in their life, when nutrition and beneficial healthcare are paramount.

This article, therefore, proposes the utilisation of corporate zakat - an annual religious obligation paid by business entities under the purview of zakat on wealth - as a means of developing a child grant that seeks to complement existing government programmes.

An ongoing study by the International Institute of Advanced Islamic Studies (IAIS) Malaysia, in collaboration with UNICEF and Iman Research, discovered that corporate zakat has the potential to address the required needs of children in Malaysia in terms of survival, nutrition, healthcare and education.

There are 693 Shariah-compliant listed companies under the Securities Commission and 16 Islamic commercial banks in Malaysia that are supposed to pay zakat. However, as of October last year, only 21 companies and 12 Islamic banks had disclosed their zakat payments, with an average payment of RM4 
million accumulating to a total collection of RM130 million. This is a far cry from the true potential of corporate zakat, which is estimated to reach around RM2.9 billion by the end of 2019 and more than RM3.4 billion by 2031. This projection, however, does not include non-public Shariah-compliant firms, soleproprietorships, Islamic cooperatives and small-medium enterprises in Malaysia. On the other hand, the total budget of the child grant system only amounted to RM1.9 billion to cater to approximately 832,940 children under the age of 2 in 2019, with each child being allocated RM150.

In Islam, zakat can be used for various socio-economic purposes, such as education, healthcare and humanitarian causes, as long as recipients fulfil the criteria of zakat beneficiaries (asnaf). The Qur'anic verse 9:60 lists eight categories of individuals deserving of zakat: the poor (al-fuqara'); the needy (al-masakin); zakat collectors; those whose hearts are being reconciled to Islam; war captives whose freedom must be bought; persons in debt; those who are in the path of Allah; and the wayfarer.

In this regard, the overwhelming majority of jurists from the four established schools (Hanafites, Malikites, Shafi'ites and Hanbalites) are of the view that children are also eligible to receive zakat if their guardians fall among the above eight categories. A hadith narrated by al-Daruquthni from Abu Juhaifah reported that the Prophet Muhammad (pbuh) once sent a zakat collector to collect zakat from the rich and redistribute it amongst the poor. At that time, Abu Juhaifah was a young orphan who did not possess any wealth, so the zakat collector gave him a middle-aged camel. Thus, according to the Hanafi school, children of wealthy parents cannot receive zakat because they are considered rich if their parents are rich. In a report attributed to Caliph Umar al-Khattab, it is stated that the first category of zakat receiver (the poor, fuqara') refers to Muslims, while the second (the needy, masakin) refers to non-Muslims. Difference of religion is thus not a bar to zakat.

In a nutshell, corporate zakat is a high-potential source of funding for a child grant programme in Malaysia, particularly for children of households belonging to the B40 category. Other potential avenues, such as corporate social responsibility (CSR), sadaqah and waqf, can also be explored as complementary funding sources for the proposed grant.

From an Islamic viewpoint, the use of corporate zakat and other Islamic social finance instruments for a child protection system correspond to the higher objectives of shariah (maqasid) concerning the protection of life and mind, and is supportive of the government's new motto to promote Islam as rahmatan lil 'alamin (a mercy to all creation).

To achieve corporate zakat's fullest collection potential, the present writer proposes that relevant authorities, such as the Securities Commission (SC), Bank 
Negara Malaysia (BNM), and the Companies Commission of Malaysia (SSM), increase the promotion and payment of zakat among Malaysian companies.

Also, corporate zakat payments need to be emphasised as a tax obligation. This is particularly so since the National Fatwa Council of Malaysia (2001) and Selangor Fatwa Council (2003) have resolved that Islamic banks and shariahcompliant firms are obligated to pay zakat.

It is also recommended that zakat payments become one of the determining criteria in achieving shariah-compliant status for public-listed securities under the SC.

\section{Notes}

* Mohammad Mahbubi Ali is Associate Fellow, International Institute of Advanced Islamic Studies (IAIS) Malaysia. Email: mahbubi@iais.org.my. 